\title{
Laju Pertumbuhan Dan Kelangsungan Hidup Ikan Lele Dumbo (Clarias gariepinus) Yang Dipelihara Pada Topografi Yang Berbeda
}

\section{Growth and survival rates of African catfish (Clarias gariepinus) which are maintained on different topography}

\author{
Abdul Qadir Jailani ${ }^{1)}$, Eric Armando*1), Muhammad Tri Aji ${ }^{1)}$ \\ 1) Fakultas Pertanian, Universitas Tidar \\ *email:ericarmando@untidar.ac.id
}

\begin{abstract}
ABSTRAK
Kondisi alam di kabupaten Magelang yang mempunyai keragaman topografi berdampak pada beragamnya suhu air di perairan. Ketidak cocokan suhu air budidaya akan direspon ikan sebagai stressor lingkungan. Ikan yang mengalami stress akan menghindari aktivitas anabolic seperti pertumbuhan dan reproduksi, dan dalam jangka panjang dapat menyebabkan terjadinya penurunan pertumbuhan, resistensi penyakit, keberhasilan reproduksi, tampilan renang dan karakteristik lain keseluruhan biota atau populasi. Penelitian ini bertujuan untuk mengetahui tingkat laju pertumbuhan dan kelangsungan hidup benih ikan lele dumbo (Clarias gariepinus). Hasil tersebut akan menjadi data yang dapat menjadi acuan untuk pengembangan budidaya ikan lele di dua kecamatan tersebut, sehingga informasi penelitian ini dapat meminimalisir lambatnya pertumbuhan ikan lele yang diakibatkan ketidakcocokkan kualitas air budidaya. Dalam penelitian ini akan didapatkan gambaran potensi lokasi yang optimal untuk budidaya lele berdasarkan letak topografi. Perlakuan topografi pada lokasi A Muntilan (Fluktuasi Suhu $21^{\circ} \mathrm{C}-24^{\circ} \mathrm{C} 348 \mathrm{mdpl}$ ), B lokasi Grabag (Fluktuasi Suhu $19^{\circ} \mathrm{C}-22^{\circ} \mathrm{C} 600 \mathrm{mdpl}$ ). Kelangsungan hidup lele pada kedua tempat penelitian didapat SR sebesar $100 \%$. Pertumbuhan berat awal ikan rata-rata sebesar 30 gr. Pada penelitian ini pertumbuhan berat tertinggi terdapat pada perlakuan Fluktuasi Suhu $21^{\circ} \mathrm{C}-24^{\circ} \mathrm{C} 348 \mathrm{mdpl}$ dimana selama pemeliharaan mengalami peningkatan pertumbuhan yang cepat dengan berat akhir rata rata $73.5 \mathrm{gr}$, mengalami penambahan berat tubuh sebesar $43.5 \mathrm{gr}$.
\end{abstract}

Kata kunci: lele dumbo; suhu; pertumbuhan; kelangsungan hidup

\section{ABSTRACT}

The natural conditions in the district of Magelang which have a diversity of topography have an impact on the diversity of water temperatures in the waters. The unsuitable temperature of aquaculture will be responded by fish as an environmental stressor. Stressed fish will avoid anabolic activities such as growth and reproduction, and in the long run can lead to decreased growth, disease resistance, reproductive success, swimming appearance and other characteristics of the whole biota or population. This study aims to determine the rate of growth and survival of African catfish (Clarias gariepinus) seeds. These results will be data that can be a reference for the development of catfish farming in the two districts, so that this research information can minimize the slow growth of catfish caused by mismatched water quality. In this research, we will get an idea of the optimal location potential for catfish cultivation based on the topographic location. Topographic treatment at location A Muntilan (Temperature Fluctuation $21^{\circ} \mathrm{C}-24^{\circ} \mathrm{C}$ $348 \mathrm{mdpl}$ ), B Grabag location (Temperature Fluctuation $19^{\circ} \mathrm{C}-22^{\circ} \mathrm{C} 600 \mathrm{mdpl}$ ). The survival of the catfish at both study sites was SR 100\%. Initial weight growth of fish on average by $30 \mathrm{gr}$. In this study the highest weight growth was found in the treatment of Fluctuations in Temperature $21^{\circ} \mathrm{C}-24^{\circ} \mathrm{C} 348 \mathrm{mdpl}$ where during maintenance experienced rapid growth growth with an average final weight of $73.5 \mathrm{gr}$, experiencing body weight gain of $43.5 \mathrm{gr}$.

Keywords: catfish dumbo; temperature; growth; survival 


\section{PENDAHULUAN}

Semakin meningkatnya permintaan pasar akan ikan lele berdampak pada meningkatnya usaha pembesaran ikan lele. Salah satu faktor yang dapat meningkatkan keberhasilan panen ikan lele adalah parameter kualitas air fisika dan kimia. Ikan sebagai organisme akuatik seringkali berhadapan dengan stressor lingkungan perairan. Stressor lingkungan yang umum bagi ikan adalah parameter kualitas air seperti suhu. Perubahan suhu di lingkungan media pemeliharaan dapat mempengaruhi kehidupan ikan bahkan dapat menyebabkan stres. Suhu yang tinggi dapat menyebabkan oksigen menurun dan mengurangi selera makan ikan. Meskipun ikan dapat beraklimatisasi pada suhu yang relatif tinggi, tetapi pada suatu derajat tertentu kenaikan suhu dapat menyebabkan kematian ikan. Perubahan drastis suhu sampai mencapai $5^{\circ} \mathrm{C}$ dapat menyebabkan stres pada ikan atau membunuhnya (Aliza, et al., 2013). Stres adalah ketidak mampuan suatu organisme mempertahankan kondisi homeostasis akibat terganggunya individu tersebut oleh adanya rangsangan dari luar yang dinamai dengan stressor (Pamungkas, 2012).

Suhu juga dapat mempengaruhi pertumbuhan ikan lele. Ikan merupakan hewan berdarah dingin sehingga metabolisme tubuh tergantung pada suhu lingkungannya, termasuk kekebalan tubuh ikan. Suhu tinggi menyebabkan ikan aktif bergerak, tidak mau berhenti makan dan metabolisme cepat meningkat sehingga kotorannya menjadi lebih banyak. Hal ini menyebabkan kebutuhan oksigen menjadi naik, sedangkan ketersediaan oksigen dalam air akan berkurang sehingga ikan akan kekurangan oksigen dalam darah, akibatnya ikan menjadi stress dan mudah terserang penyakit. Faktor lingkungan yang paling mengatur kecepatan pertumbuhan adalah suhu air (Taufik, et al., 2009).

Ikan yang mengalami stress akan menghindari aktivitas anabolic seperti pertumbuhan dan reproduksi, dan dalam jangka panjang dapat menyebabkan terjadinya penurunan pertumbuhan, resistensi penyakit, keberhasilan reproduksi, tampilan renang dan karakteristik lain keseluruhan biota atau populasi (Armando, et al., 2017).

Ikan lele dumbo (Clarias gariepinus) mempunyai pertumbuhan yang cepat, resisten terhadap penyakit, memlikiki kemampuan toleransi terhadap pameter lingkungan dalam batas yang luas serta dagingnya berkualitas baik. Oleh karena itu ikan lele dumbo tergolong spesies ikan yang potensial untuk dibudidayakan (Hastuti dan Subandiyono, 2014).

Walaupun ikan mampu mentolerir perubahan kualitas air, pada sebagian besar spesies ikan, suhu diatas optimum dapat mengakibatkan meningkatnya laju metabolisme dan energi mulai dialihkan dari pertumbuhan untuk laju metabolisme yang tinggi sehingga laju pertumbuhan menjadi menurun. Penurunan kualitas air dapat menyebabkan stress pada ikan, bahkan apabila penurunan mutu air telah melampaui batas toleransi maka akan berakibat pada kematian (Armando, et al., 2018).

Oleh karena itu, perlu adanya penelitian mengenai laju pertumbuhan dan kelangsungan hidup pada ikan lele yang dipelihara pada topografi berbeda untuk memberikan informasi tambahan kelayakan lahan budidaya lele di daerah dataran tinggi.

\section{MATERI DAN METODE}

Penelitian ini akan dilaksanakan pada bulan Juli sampai dengan Agustus 2018 bertempat di Kelompok Tani perbatasan Secang Grabag dan Balai Benih Ikan Kecamatan Muntilan Kabupaten Magelang. Pengamatan yang dilakukan yaitu pengukuran tingkat kelangsungan hidup dan pertumbuhan serta parameter kualitas air. Penelitian ini menggunakan benih ikan lele berukuran $15 \mathrm{~cm}$, dengan padat penebaran 200 ekor/Lokasi.

Kelangsungan hidup ikan uji diamati berdasarkan jumlah total ikan pada saat awal penebaran sampai akhir percobaan yang dilakukan pada setiap unit percobaan. Pengukuran bobot tubuh ikan dilakukan dari awal penebaran hingga akir percobaan. Untuk pengukuran bobot tubuh diukur menggunakan timbangan digital. Selanjutnya data di Uji normalitas untuk melihat apakah sampel berasal dari populasi berdistribusi normal atau tidak. Pengujian normalitas data sampel dalam penelitian ini menggunakan OneSample Kolmogorov-Smirnov ( Uji K-S ) dengan bantuan SPSS. Kemudia dilanjutkan dengan uji t sampel berpasangan.

\section{HASIL DAN PEMBAHASAN}

Suhu mempengaruhi kelangsungan hidup kan lele yang dipelihara selama 30 hari dengan kepadatan 200 ekor/kolam. Berat awal ikan lele sebesar 30 gr. Tingkat kelangsungan 
hidup ikan lele selama pemeliharaan diperoleh dari mencatat jumlah ikan yang mati setiap harinya dan menghitung jumlah ikan yang hidup di akhir pemeliharaan. Kelangsungan hidup lele pada kedua tempat penelitian didapat SR sebesar $100 \%$.

Tabel 1. Kelangsungan Hidup (\%) ikan lele selama penelitian

\begin{tabular}{lcl}
\hline Perlakuan & SR & $\begin{array}{c}\text { Jumlah } \\
\text { Ikan }\end{array}$ \\
\hline $\begin{array}{l}\text { A (Fluktuasi Suhu } 21^{\circ} \mathrm{C}- \\
24^{\circ} \mathrm{c}, 348 \text { mdpl, Muntilan) }\end{array}$ & $100 \%$ & 200 \\
& & \\
B (Fluktuasi Suhu $19^{\circ} \mathrm{C}-$ & $100 \%$ & 200 \\
$22^{\circ} \mathrm{C}, 600 \mathrm{mdpl}$, Grabag) & & \\
\hline
\end{tabular}

Tidak adanya perbedaan hasil yang signifikan antar perlakuan dikarenakan ikan lele memiliki respon adaptasi yang tinggi. Fluktuasi suhu pada lokasi penelitian tidak melebihi $5^{\circ} \mathrm{C}$. Perubahan temperatur sebesar $5^{\circ} \mathrm{C}$ di atas normal dapat menyebabkan stres pada ikan bahkan kerusakan jaringan dan kematian (Kordi, 2000). Temperatur tinggi yang masih dapat ditoleransi tidak selalu berakibat mematikan pada ikan tetapi dapat menyebabkan gangguan status kesehatan untuk jangka panjang, misalnya stres yang ditandai dengan tubuh lemah, kurus, dan tingkah laku abnormal (Irianto, 2005 dalam Armando et al 2018).

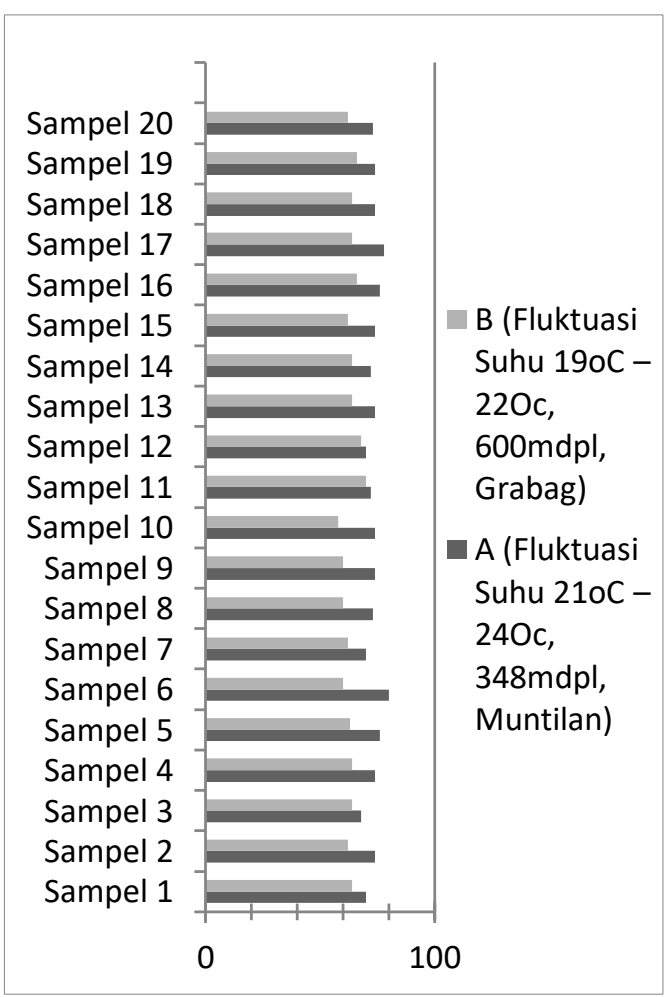

Grafik 1. Pertumbuhan berat (gr) akhir ikan lele Pertumbuhan berat awal ikan rata-rata sebesar 30 gr. Pada penelitian ini pertumbuhan berat tertinggi terdapat pada perlakuan A Fluktuasi Suhu $21^{\circ} \mathrm{C}-24^{\circ} \mathrm{C} 348 \mathrm{mdpl}$ dimana selama pemeliharaan mengalami peningkatan pertumbuhan yang cepat dengan berat akhir rata rata $73.5 \mathrm{gr}$, mengalami penambahan berat tubuh sebesar 43.5 gr, Sedangkan pada perlakuan B (Fluktuasi Suhu $19^{\circ} \mathrm{C}-22^{\circ} \mathrm{c}, 600 \mathrm{mdpl}$, Grabag) berat akhir rata rata diperoleh sebesar $63,35 \mathrm{gr}$, mengalami penambahan 33,35gr. Setiap spesies ikan memiliki suhu optimum, yaitu kisaran suhu dimana pertumbuhan dapat mencapai optimum, suhu di luar kisaran tersebut secara terus menerus akan menyebabkan stress dan bahkan kematian. Pada lokasi muntilan tersebut merupakan lokasi yang terbaik dibandingkan grabag untuk pemeliharaan ikan lele. Kondisi tersebut menyebabkan proses pencernaan berjalan lancar dan akan memacu penyerapan makanan, sehingga laju pengosongan lambung akan berjalan cepat. Hal demikian akan menyebabkan konsumsi pakan meningkat sehingga pakan yang dikonsumsi akan lebih banyak dan pertumbuhannya pun akan lebih optimal (Stickney, 2000). Suhu berpengaruh terhadap pertumbuhan, kecepatan makan, waktu metamorfosis, tingkah laku, kecepatan berenang, penyerapan dan laju pengosongan lambung serta metabolism (Blaxter 1998 dalam Ardimas, 2012).

Lambatnya pertumbuhan pada lokasi grabag disebabkan karena suhu menyebabkan beban kerja metabolisme menjadi besar, sehingga energi yang digunakan untuk proses metabolisme tersebut semakin besar dan pertumbuhan menjadi tidak optimal. Sebagian besar spesies ikan, suhu diatas optimum dapat mengakibatkan meningkatnya laju metabolisme dan energi mulai dialihkan dari pertumbuhan untuk laju metabolisme yang tinggi sehingga laju pertumbuhan menjadi menurun (Stickney, 1979). Berdasarkan hasil uji $\mathrm{t}$ - test di dapat hasil bahwa $\mathrm{t}$ hitung $<\mathrm{t}$ table dengan tingkat kepercayaan $95 \%$,yaitu $24,7139<2,093$. Hal ini menunjukkan bahwa ada pengaruh yang signifikan antara pemberian perlakuan lokasi dengan fluktuasi suhu yang berbeda terhadap laju pertumbuhan ikan lele.

Kisaran oksigen selama penelitian masih dalam kisaran antara 4,2-7,7 $\mathrm{mg} / \mathrm{L}$ dengan pemberian aerasi sehingga oksigen terlarut tetap stabil. sesuai dengan pernyataan Boyd (1990), 
pertumbuhan dan sintasan ikan baik pada nilai DO $>3,5 \mathrm{mg} / \mathrm{L}$.

\section{KESIMPULAN}

Berdasarkan penelitian yang dilakukan dapat diambil kesimpulan sebagai berikut:

- Perlakuan perbedaan topografi pada tingkat kelangsungan hidup ikan lele tidak berbeda nyata.

- Pertumbuhan berat tertinggi terdapat pada perlakuan lokasi Muntilan dengan Fluktuasi Suhu $21^{\circ} \mathrm{C}-24^{\circ} \mathrm{C} 348 \mathrm{mdpl}$ dimana selama pemeliharaan mengalami peningkatan pertumbuhan yang cepat dengan berat akhir rata rata $73.5 \mathrm{gr}$, mengalami penambahan berat tubuh sebesar $43.5 \mathrm{gr}$.

\section{DAFTAR PUSTAKA}

Aliza, D., Winaruddun dan W,S Luky. 2013. Efek Peningkatan Suhu Air Terhadap Perubahan Perilaku, Patologi Anatomi dan Histopatologi Insang Ikan Nila (Oreochromis niloticus). Jurnal Medika Veterinaria. 7(2):142-145.

Ardimas, Y. A. Y. 2012. Pengaruh Gradien Suhu media pemeliharaan terhadap pertumbuhan dan kelangsungan hidup larva ikan betok (Anabas testudineus Bloch). Teknologi dan Manajemen Perikanan Budidaya. Institut Pertanian Bogor. Skripsi.

Armando, E., W,S Maheno dan M, Fadjar. 2017. Physiological Respons of Gouramy Fry (Osphronemus Gouramy) to Different Temperatures. International Journal of Chemtech Research. 10(4):664-668

Armando, E., W,S Maheno dan M. Rasyid. 2018. The Effect of Different Temperature Toward The Survival Rate and Specific Growth Rate of The Silver Arwana Fish (Osteoglossum bicirrhosum). Journal of Aquaculture Development and Environment. 1(1):31-34.

Boyd, C. E. 1990. Water Quality in Ponds for Aquaculture. Alabama Agricultural Experiment Station. Aburn Station. Birmingham Publishing Co. $482 \mathrm{hlm}$.

Hastuti, S dan Subandiyono. 2014. Performa Produksi Ikan Lele Dumbo (Clarias gariepinus) Yang Dipelihara Dengan Teknologi Biofloc. Jurnal Saintek Perikanan. 10(1):37-42.

Kordi, K. 2000. Budidaya Ikan Nila. Cetakan ke2. Dahara Prize, Semarang.
Pamungkas, W. 2012. Aktivitas Osmoregulasi, Respons Pertumbuhan, dan Energetic Cost pada Ikan yang Dipelihara dalam Lingkungan Bersalinitas. Media Akuakultur. 7(1):44-51.

Stickney R.R ., 2000. Encyklopedia of Aquaculture. A Wiley Interscience Publication, John Wiley and Sons, Inc. New York, 136-293 hlm.

Taufik, I. Zahri I,A. dan Sutrisno. 2009. Pengaruh Perbedaan Suhu Air pada Pemeliharaan Benih Ikan Betutu (Oxyeleotris marmorata Blkr) Dengan Sistem Resirkulasi. Jurnal Riset Akuakultur. 4(3):319-325. 